\title{
PENGEMBANGAN PAKET PELATIHAN MENULIS EKSPRESIF SEBAGAI MEDIA KATARSIS KECEMASAN SISWA INTROVERTDI SMA
}

\author{
Hikmah Ilmiyana \\ Bimbingan dan Konseling, Universitas Negeri Malang, Jl. Semarang 5 Malang 65145 \\ Email: ilmiyanah@gmail.com. 081333347612
}

\begin{abstract}
The purpose of this study was to develop a training package expressive writing as catharsis media introverted high school student anxiety. The research model used adapts from Borg and Gall. The product has been through expert test of BK, media, language and test of product user candidate and operational test. Data were collected using an anxiety scale questionnaire, introverted questionnaires, interviews and documentation studies. Data analysis techniques use descriptive statistics. The distribution of anxiety scale questionnaires and introverted scale is done in SMA 1 Pasuruan, distributed to 70 students in grade 10. From the division of questionnaires proved some students have high levels of anxiety and tend to introvert. Results of the assessment expert testing and test prospective users stating the product has met the eligibility criteria, accuracy, usefulness, the attractiveness and convenience. The results of product operational tests show that there are differences in anxiety levels of students before and after being treated using expressive writing training packages. For the introverted scale there are differences in introverted levels of students before and after being treated.
\end{abstract}

Keywords : Training Packages, Expressive Writing, Catharsis, Anxiety, Introverts.

Abstrak : Tujuan penelitian mengembangkan paket pelatihan menulis ekspresif sebagai media katarsis kecemasan siswa introvert di SMA. Model penelitian yang digunakan mengadaptasi dari Borg and Gall. Produk telah melalui uji ahli BK, media, bahasa dan uji calon pengguna produk serta uji operasional. Data dikumpulkan dengan menggunakan angket skala kecemasan, angket introvert, wawancara dan studi dokumentasi.Teknik analisis data menggunakan statistik deskriptif. Dari pembagian angket skala kecemasan dan skala introvertkepada 70 siswa kelas XI secara acak di SMAN 1 Pasuruan terbukti beberapa siswa memiliki tingkat kecemasan tinggi dan cenderung introvert. Hasil penilaian uji ahli dan uji calon pengguna menyatakan produk sudah memenuhi kriteria kelayakan, ketepatan, kegunaan, kemenarikan dan kemudahan. Hasil uji operasional produk menunjukkan terdapat perbedaan tingkat kecemasan siswa sebelum dan sesudah diberi perlakuan.

Kata Kunci: Paket pelatihan, Menulis ekspresif, Katarsis, Kecemasan, Introvert

\section{PENDAHULUAN}

Freud(dalam Alwisol, 2008)

mendefinisikan

sebagaifungsi

kecemasan

memperingatkan individu tentang

kemungkinan datangnya suatu bahaya

sehingga dapat disiapkan reaksi secara langsung baik verbal maupun non verbal, kecemasan akan menjadi permasalahan yang cukup menyita perkembangannya. Hal ini dikarenakan sikap introvert cenderung sulit untuk mengungkapkan dan mengekspresikan apa yang 
EISN: -

Jurnal Konseling Pendiolikan Islam

Vol. 01 No. 01, Januari 2020

dirasakannya. Ketika seseorang juga dapat digunakan sebagai media memiliki kesulitan untuk mengekspresikan emosinya yang terjadi adalah penumpukan energi negatif yang dapat mempengaruhi sikap dan pemikirannya.

Sikap introvert memiliki ciri-ciri yaitu mengarahkan pribadi ke pengalaman subjektif, cendrung menyendiri, pendiam, atau tidak ramah, bahkan antisosial (Alwisol, 2009). Banyak cara yang dapat digunakan sebagai media penyaluran kecemasan, salah satu cara penyaluran adalah menulis.

Menulis terbukti bisa menjadi alternatif terapi, baik terapi emosi, perilaku, maupun penyakit medis. Menulis tepat digunakan untuk siswa introvert karena sifatnya yang lebih pribadi dan rahasia. Salah satu terapi menulis yang telah banyak dilakukan adalah expressive writing. Expressive writing atau menulis ekspresif pertama kali di kemukakan oleh James W. Pennebaker (dalam Adams, 2013) studinya mengenai menulis ekspresif menyatakan bahwaseseorang yang menuangkan pikiran dan perasaan terdalam selama empat bulan sesudahnya menjadi jarang sakit. Kondisi psikologis mereka bertambah baik dalam jangka panjang dan jarang menemui persoalan kesehatan.Menulis katarsis siswa.

Istilah katarsis pertama kali dibahas dalam karya Aristoteles, dia menggunakan istilah katarsis untuk menggambarkan pelepasan dan purifikasi emosional. Istilah katarsis juga diperkenalkan oleh Freud dan Breuer, 1893 (dalam Bertens, 2007:56) dalam kasusnya yang terkenal yaitu hysteria Anna $\mathrm{O}$, studies of hysteria yang menghasilkan pengobatan dengan bicara katarsis.

Proses katarsis ini sangat penting bagi siswa yang sedang menghadapi masalah emosional yang dapat menimbulkan kecemasan. Siswa yang sedang menghadapi masalahmasalah emosional umumnya mereka menghadapi situasi yang menyedihkan, mengecewakan, dan menjengkelkan. Khususnya bagi siswa yang memiliki kecenderungan bersikap introvert yaitu siswa yang memendam dan

sukarmenceritakanpermasalahannya kepada orang lain.

Peran seorang konselor sangat dibutuhkan ketika siswa mengalami kecemasan, siswa memerlukan bantuan untuk mengurangi tingkat kecemasan yang dirasakan agar tidak berdampak pada kehidupan pribadi, sosial, dan prestasi belajarnya. Tujuan 
bimbingan dan konseling salah satunya adalah mengatasi hambatan dan kesulitan yang dihadapi siswa dalam belajar menyesuaikan diridengan lingkungan pendidikan, masyarakat, maupun lingkungan kerja (Santoso, 2009) Namun pada kenyataan dilapangan masih banyak ditemukan peran dan fungsi bimbingan dan konseling di sekolah kurang maksimal.

Penelitian ini difokuskan pada cara dalam mengatasi kecemasan siswa terutama kepada siswa yang cenderung memiliki sikap introvert (tertutup). Banyak dampak yang ditimbulkan dari kecemasan yang tidak segera diselesaikan, oleh karena itu penelitian ini dilakukan untuk mengembangakan sebuah media berupa paket pelatihan menulis ekspresif sebagai media katarsis kecemasan siswa introvert di SMA.

\section{METODE PENELITIAN}

Penelitian ini dilaksanakan di SMAN 1 Pasuruan. Pemilihan tempat berdasarkan pengalaman dan pengamatan selama satu bulan di sekolah sebelum penelitian. Pada awal penelitian dilakukan proses wawancara dengan konselor sekolah dan beberapa siswa di sekolah. Setelah wawancara, selanjutnya melakukan penyebaran angket skala introvert dan angket skala kecemasan, proses penyebaran dilakukan pada dua kelas yaitu kelas XI MIA 1 dan XI MIA 4 dengan jumlah keseluruhan sebanyak 70 siswa.

Metode penelitian ini adalah penelitian kuantitatif dengan mengunakan pendekatan yang mengadaptasi Research and Development dari Borg and Gall (1983). Langkah-langkahnya yaitu: 1) Melakukan penelitian pendahuluan; 2) Melakukan perencanaan; 3) Mengembangkan prototype produk awal; 4) Melakukan uji coba lapangan tahap awal; 5) Melakukan revisi terhadap produk; 6) Melakukan uji coba kelompok kecil; 7) Melakukan revisi terhadap produk operasional; 8) Melakukan uji lapangan operasional; 9) Melakukan revisi terhadap produk akhir; 10) Menyusun produk akhir paket pelatihan menulis ekspresif sebagai media katarsis kecemasan siswa introvert di SMA.

Produk yang dihasilkan telah melalui uji ahli materi BK, uji ahli media, uji ahli bahasa dan uji calon pengguna produk serta uji operasional. Data uji ahli materi BK dianalisis menggunakan model kesepakatan (inter-rater agreement model) sedangkan untuk data uji ahli media 
dan uji ahli bahasa data dianalisis menggunakan rumus rata-rata. Uji calon pengguna dilakukan oleh dua konselor dan tujuh siswa. Uji operasional dilakukan setelah uji calon pengguna, sebanyak delapan siswa yang terpilih untuk mengikuti uji operasional produk, pemilihan siswa berdasar atas hasil analisis angket yang telah dilakukan sebelumnya. Delapan siswa tersebut mengikuti serangkaian kegiatan yaitu, mengisi angket pretest dan posttest dan mengikuti kegiatan sesuai dengan tahapan dalam paket pelatihan menulis ekspresif.

Hasil pretest dan posttest dianalisis menggunakan teknik analisis data non parametrik yaitu teknik Wilcoxon. Teknik analisis Wilcoxon dilakukan dengan cara menghitung taraf signifikansi perbedaan rerata kecemasan siswa sebelum dan sesudah diberikan perlakukan kegiatan konseling menggunakan paket pelatihan menulis ekspresifdi SMA. Perhitungan dilakukan dengan bantuan program SPSS for windows20.00.

\section{HASIL PENELITIAN}

Penyebaran angket skala kecemasan dan angket skala introvert dilakukan pada kelas XI MIA 1 dan XI
MIA 4 dengan total siswa sebanyak 70 siswa. Data diperoleh menunjukkan, 2 siswa $(2,9 \%)$ tingkat kecemasan tinggi, 51 siswa $(72,8 \%)$ tingkat kecemasan sedang dan 17 siswa (24,3\%) tingkat kecemasan ringan. Untuk angket skala introvert diperoleh data 12 siswa $(17,1 \%)$ memiliki kecenderungan introvert sangat tinggi dan 2 siswa $(2,9 \%)$ siswa memiliki tingkat introvert sedang dan 56 (80\%) siswa memiliki kecenderungan introvert tinggi. Dengan demikian terbukti bahwasannya terdapat siswa yang mengalami kecemasan dengan kategori tinggi.

Penelitian ini menghasilkan sebuah produk berupa paket pelatihan menulis ekspresif untuk siswa dan paket panduan untuk konselor. Paket pelatihan untuk siswa terdiri dari cover depan dan belakang, kata pengantar, daftar isi. Selanjutnya adalah penjelasan mengenai paket pelatihan berisi materi-materi yang terkait dengan paket pelatihan menulis ekspresif. yaitu materi mengenai menulis ekspresif, kecemasan, katarsis dan introvert. Pada bagian inti merupakan tahapan-tahapan paket pelatihan, terdapat 6 tahapan dan evaluasi.

Paket panduan untuk konselor, bagian depannya terdiri dari cover 
depan dan belakang, kata pengantar, Daftar isi. Paket panduan untuk konselor terdiri dari tiga bab yang pertama adalah bab I pendahuluan berisi mengenai latar belakang, tujuan penggunaan paket, sasaran pengguna, materi paket pelatihan dan komponen pengembangan. Bab II yaitu materi pengenalan paket, terdapat 4 materi yang dijelaskan yaitu materi 1 (kecemasan), materi 2 (introvert), materi 3 (katarsis), materi 4 (paket pelatihan menulis ekspresif). Bab III merupakan tahapan pelatihan, bab ini menjelaskan mengenai tahapantahapan dalam paket pelatihan.

Produk pengembangan ini telah melalui serangkaian uji ahli, yaitu uji ahli materi BK, uji ahli media, uji ahli bahasa, uji pengguna produk dan uji operasional. Data hasil penilaian ahli materi di analisis menggunakan interrater agreement model. Hasil yang diperoleh untuk penilaian tehadap paket pelatihan siswa dan paket panduan untuk konselor adalah 1 yang berarti memiliki validitas dan relevansi yang sangat tinggi dari ahli satu dan ahli dua. Dengan demikian paket pelatihan menulis ekspresifsecara umum sudah baik. Hasil penilaian ahli media pada paket pelatihan menulis ekspresifuntuk siswa adalah rata-rata penilaian dari aspek ketepatan adalah 3.9, untuk aspek kegunaan rata-rata mencapai 4 , aspek kemudahan nilai rata-rata mencapai 4 dan rerata penilaian aspek kemenarikan diperoleh hasil sebesar 4. Dengan demikian media dalam bentuk paket pelatihan menulis ekspresifini sangat tepat, berguna, mudah dipahami dan menarik utamanya untuk siswa SMA.

Hasil penilaian ahli media pada paket panduan menulis ekspresifuntuk konselor, diketahui rata-rata penilaian dari aspek pendahuluan adalah 4, untuk aspek petunjuk kegunaan juga memperoleh hasil rata-rata 4. Rerata penilaian dari aspek kegiatan bimbingan konseling memperoleh 4 kemudian rerata penilaian aspek prosedur pelaksanaan layanan juga memperoleh rata-rata 4, dua aspek terakhir yaitu aspek sistematika penulisan dan kelengkapan paket pelatihan untuk konselor mendapatkan rata-rata yang sama yaitu 4. Dengan demikian media dalam bentuk paket pelatihan menulis ekspresifini secara umum menurut ahli media sudah bagus.

Hasil penilaian dari ahli bahasa pada paket pelatihan menulis ekspresifuntuk siswa menghasil kan data sebagai berikut, rata-rata penilaian dari aspek ketepatan adalah 
3, untuk aspek kegunaan rata-rata mencapai 3.2 , rerata penilaian dari aspek kemudahan memperoleh 3.2 dan rerata penilaian aspek kemenarikan diperoleh hasil sebesar 3.3. Hasil penilaian ahli media pada paket pelatihan menulis ekspresifuntuk konselor menghasilkan data rata-rata penilaian dari aspek pendahuluan adalah 3.2, untuk aspek petunjuk kegunaan memperoleh hasil rata-rata 3. Rerata penilaian dari aspek kegiatan bimbingan konseling memperoleh 3 kemudian rerata penilaian aspek prosedur pelaksanaan layanan juga memperoleh rata-rata 3 , dua aspek terakhir yaitu aspek sistematika penulisan dan kelengkapan paket pelatihan untuk konselor mendapatkan rata-rata yang sama yaitu 3 .

Dengan demikian media dalam bentuk paket pelatihan menulis ekspresifini baik untuk siswa dan panduan untuk konselor secara umum menurut ahli bahasa sudah cukup bagus hanya ada beberapa yang masih perlu perbaikan terutama dalam hal penulisan.Setelah melaksanakan uji ahli materi BK, uji ahli media dan uji ahli bahasa maka dilakukan revisi. Masukan-masukan dari para ahli diaplikasikan di dalam produk. Setelah revisi dilakukan maka tahap selanjutnya adalah uji pengguna produk, uji pengguna produk dilakukan kepada dua orang konselor dan tujuh siswa SMAN 1 Pasuruan.

Dari hasil penilaian dua konselor sebagai uji pengguna produk 1 , diketahui rata-rata penilaian dari aspek ketepatan adalah 3,7. Rerata dari aspek kegunaan adalah 3,8. Rerata penilaian dari aspek kemudahan yaitu 3,1 dan rerata penilaian untuk aspek kemenarikan adalah 3,8. Hasil keseluruhan ratarata penilaian paket pelatihan dari lima aspek tersebut adalah 3.6, dengan demikian paket pelatihan menulis ekspresifsebagai media katarsis kecemasan siswa introvert dinyatakan tepat, berguna, menarik dan mudah untuk diaplikasikan dalam kegiatan bimbingan dan konseling di SMA, sedangkan penilaian untuk paket panduan konselor, diketahui nilai ratarata pada aspek pendahuluan adalah 3,7 , rerata untuk aspek petunjuk penggunaan yaitu 4 .

Penilaian rata-rata untuk aspek kegiatan dalam bimbingan dan konseling adalah 3,7 dan rerata untuk aspek prosedur pelaksanaan yaitu sebesar 3,8. Jumlah nilai rata-rata keseluruhan aspek terhadap paket panduan untuk konselor ini sebesar 3,8. Jadi secara umum paket pelatihan untuk konselor sudah baik. Uji 
pengguna produk II yaitu dilaksanakan oleh tujuh siswa menghasilkan nilai rata-rata penilaian keseluruhan paket pelatihan menulis ekspresif sebesar 3,56. Dengan demikian dapat disimpulkan bahwa paket pelatihan menulis ekspresif ini sudah memenuhi kriteria ketepatan, kemudahan, kelayakan dan kemenarikan untuk siswa SMA. Setelah melaksanakan uji calon pengguna produk, langkah selanjutnya dalah melakukan revisi, masukan dari konselor dan siswa menjadi bahan utama. Revisi pada tahap ini merupakan revisi terakhir sebelum dilaksanakan uji operasional.

Uji operasional dilaksanakan untuk mengetahui keefektifan paket pelatihan menulis ekspresif terhadap tingkat kecemasan siswa yang diketahui dari hasil pretest dan posttest siswa. Uji operasional dilaksanakan oleh delapan siswa yang dipilih berdasarkan hasil analisis angket kecemasan dan angket introvert yang telah dikerjakan sebelumnya. Berikut data yang diperoleh dari uji operasional :

Tabel Hasil Pretest-Posttest Uji Lapangan Dengan Skala Kecemasan

\begin{tabular}{|c|c|c|c|c|}
\hline $\begin{array}{c}\text { Nama } \\
\text { siswa }\end{array}$ & $\begin{array}{c}\text { Pre } \\
\text { test }\end{array}$ & Ket & $\begin{array}{c}\text { Post } \\
\text { test }\end{array}$ & Ket \\
\hline US & 167 & Tinggi & 108 & Sedang \\
\hline
\end{tabular}

\begin{tabular}{|l|l|l|l|l|} 
WMJA & 170 & Tinggi & 122 & Sedang \\
\hline HRKA & 164 & Tinggi & 117 & Sedang \\
\hline MGA & 159 & Tinggi & 112 & Sedang \\
\hline DNS & 163 & Tinggi & 124 & Sedang \\
\hline RES & 167 & Tinggi & 121 & Sedang \\
\hline ATP & 125 & Sedang & 95 & Ringan \\
\hline IRA & 172 & Tinggi & 125 & Sedang \\
\hline
\end{tabular}

Tabel Hasil Pretest-Posttest Uji Lapangan Dengan Skala Introvert

\begin{tabular}{|l|l|l|l|l|}
\hline Nama & $\begin{array}{c}\text { Pre } \\
\text { test }\end{array}$ & Ket & $\begin{array}{c}\text { Post } \\
\text { test }\end{array}$ & $\begin{array}{c}\text { Katego } \\
\text { ri }\end{array}$ \\
\hline US & 117 & Tinggi & 116 & Tinggi \\
\hline WMJA & 122 & Tinggi & 118 & Tinggi \\
\hline HRKA & 121 & Tinggi & 121 & Tinggi \\
\hline MGA & 118 & Tinggi & 113 & Tinggi \\
\hline DNS & 117 & Tinggi & 117 & Tinggi \\
\hline RES & 126 & Tinggi & 126 & Tinggi \\
\hline ATP & 123 & Tinggi & 121 & Tinggi \\
\hline IRA & 114 & Tinggi & 113 & Tinggi \\
\hline
\end{tabular}

Dari tabel diatas terdapat adanya perbedaan antara hasil pretest dan posttest tingkat kecemasan dan introvert siswa, untuk hasil pretest dan posttest tingkat kecemasan siswa mengalami penurunan yang cukup tinggi, hampir semua siswa mengalami penurunan tingkat kecemasan sesuai diberi perlakuan dengan menggunakan paket pelatihan menulis ekspresif. Sedangkan untuk hasi pretest dan posttest skala introvert terdapat penurunan akan tetapi tidak terlalu besar bahkan tiga siswa tidak mengalami perubahan, angka pretest 
dan posttest ketiga siswa tersebut sama. Dari hasil tersebut dapat dikatakan bahwasannya paket pelatihan menulis ekspresif ini cukup efektif dalam menunrunkan kecemasan siswa akan tetapi kurang berpengaruh terhadap sikap introvert siswa.

Perhitungan hasil pretest dan posttest terhadap tingkat kecemasan siswa dengan menggunakan uji Wilcoxon pada SPSS 20.00 diperoleh hasil perbandingan antara hasil pretest-posttets dari uji statistic deskriptif, dengan jumlah subjek penelitian sebanyak 8 siswa. Dari hasil descriptive statistics diketahui nilai rata-rata pretest sebesar 160,8750 dengan nilai minimum 125 dan nilai maksimum 172. Sedangkan rata-rata nilai posttest sebesar 115,5000 dengan nilai minimum 95 dan nilai maksimum 125. Pada tabel Wilcoxon signed rank test diketahui nilai positive rank sebesar $0^{\mathrm{b}}$ dan nilai negative rank sebesar $8^{a}$ yang berarti nilai posttest lebih kecil dari pada nilai pretest. Sedangkan nilai ties sebanyak 0 yang berarti tidak ada nilai posttest yang sama dengan nilai pretest. Sedangkan pada tabel test statistic didapatkan nilai Z hitung sebesar $-2,533^{\mathrm{b}}$ dan signifikansi sebesar 0,011. Karena nilai signifikansi (derajat kesalahan) yang lebih kecil dari alpha 5\% $(0,011<0,050)$ maka H0 ditolak. Sedangkan nilai Z hitung lebih kecil dari pada Z tabel ($2,533<1,96)$ sehingga H0 ditolak. Karena H0 ditolak, maka ada perbedaan tingkat kecemasan siswa sebelum dan sesudah diberi perlakuan menggunakan paket pelatihan menulis ekspresif sebagai media katarsis kecemasan siswa introvert di SMA.

Hasil pretest dan posttest untuk skala introvert siswa pada tabel Wilcoxon Signed Ranks Test, diketahui nilai negative rank sebesar $5^{\text {a }}$ dan nilai positive rank sebesar $0^{\mathrm{b}}$ yang berarti nilai posttest lebih kecil dari pada nilai pretest dengan jumlah subjek sebanyak 8 siswa. Sedangkan nilai ties sebanyak 3 yang mengartikan bahwa terdapat nilai pretest dan posttest yang sama hal ini menunjukkan bahwasannya memang ada penurunan pada nilai posttest akan tetapi terdapat 3 siswa yang nilai pretest dan posttesnya sama, hal ini menjelaksan bahwa 3 siswa tersebut tidak ada perubahan sebelum dan sesudah mendapatkan konseling dengan media paket pelatihan menulis ekspresifini. Sedangkan pada tabel test statistic didapatkan nilai $\mathrm{Z}$ hitung sebesar 2,032 ${ }^{\mathrm{b}}$ dan signifikansi sebesar 0,042. Karena nilai signifikansi (derajat kesalahan) yang lebih kecil dari alpha 
$5 \%(0,042<0,050)$ maka H0 ditolak.

Sedangkan nilai Z hitung lebih kecil dari pada $\mathrm{Z}$ tabel $\quad(-2,032<1,96)$ sehingga H0 ditolak. Karena H0 ditolak, maka ada perbedaan tingkat introvert siswa sebelum dan sesudah diberi perlakuan menggunakan paket pelatihan menulis ekspresif. Meskipun secara kategori masih sama dalam tingkatan kategori tinggi akan tetapi jika dilihat dari tabel diatas terdapat sedikit penurunan.

\section{PEMBAHASAN}

Produk akhir yang dihasilkan dari pengembangan ini adalah paket pelatihan menulis ekspresifsebagai media katarsis kecemasan siswa introvert, terdapat dua paket pelatihan yang dihasilkan yaitu paket pelatihan menulis ekspresifuntuk siswa dan paket pelatihan (panduan) untuk konselor. Pengembangan paket pelatihan menulis ekspresifsebagai media katarsis kecemasan siswa introvert ini telah melalui beberapa proses penilaian dan proses revisi. Penilaian dilakukan oleh ahli BK, ahli media, ahli bahasa, dan calon pengguna produk (konselor dan siswa SMA Negeri 1 Pasuruan) serta uji lapangan operasional pada delapan siswa kelas XI SMA Negeri 1 Pasuruan.
Produk berupa paket pelatihan menulis ekspresifini dikembangkan berdasarkan pada pengalaman peneliti dilapangan, kajian teori, dan wawancara dengan konselor, selain itu data juga diperoleh dari penyebaran angket skala kecemasan dan angket skala introvert. Hasil penyebaran angket skala kecemasan dan angket introvert tersebut membuktikan bahwasannya terdapat beberapa siswa di SMAN 1 Pasuruan yang mengalami tingkat kecemasan tinggi dan siswa tersebut cenderung introvert, atas hasil tersebut peneliti melanjutkan untuk mengembangkan paket pelatihan menulis ekspresifkarena dinilai benarbenar bermanfaat dan dibutuhkan oleh siswa untuk membantu menurunkan tingkat kecemasan yang dirasakannya.

Produk berupa paket pelatihan menulis ekspresifini digunakan oleh konselor dalam memberikan pelayanan bimbingan dan konseling yang bertujuan untuk mengurangi tingkat kecemasan siswa terutama siswa yang cenderung tertutup, siswa yang mengalami kesulitan beradaptasi, siswa yang dikucilkan dalam kelas, dengan tujuan agar siswa tersebut dapat mengembangkan diri secara optimal, dan mencapai kematangan emosi yang sesuai sehingga dapat 
membuat pilihan tentang dirinya dan menyelesaikan masalahnya.

Paket pelatihan menulis ekspresifini dilengkapi dengan panduan penggunaannya bagi konselor. Dalam panduan penggunaan bagi konselor berisi petunjuk penggunaan paket pelatihan secara umum, latar belakang paket pelatihan, tujuan umum paket pelatihan, pertemuan dan tahapan dalam paket pelatihan, indikator keberhasilan, evaluasi dan penguatan yang dapat disampaikan oleh konselor pada setiap pertemuan.

Untuk paket pelatihan menulis ekspresifsiswa disusun secara sistematis sesuai dengan tahapan Menurut Pearson \& Wilson (2001) dilengkapi dengan tujuan dan petunjuk cara pengerjaan pada setiap tahapan.

Produk pengembangan berupa paket pelatihan menulis ekspresifsebagai media katarsis kecemasan siswa introvert baik untuk siswa maupun konselor ini telah diuji coba dan direvisi. Hasil uji coba dari ahli materi BK, ahli media, ahli bahasa dan uji coba calon pengguna produk (konselor dan siswa SMA Negeri 1 Pasuruan) baik secara kuantitatif maupun kualitatif menjadi dasar untuk melakukan revisi terhadap produk. Setelah paket pelatihan direvisi maka dapat diketahui paket pelatihan sudah memenuhi spesifikasi produk pengembangan. Produk dinyatakan sudah memenuhi kriteria sangat layak, sangat tepat, sangat menarik, dan sangat mudah untuk diaplikasikan oleh siswa SMA, sehingga paket pelatihan ini dapat dipercaya dari aspek keberterimaannya secara teori maupun praktis.

Sedangkan untuk mengetahui tingkat efektifitas paket pelatihan menulis ekspresifsebagai media katarsis kecemasan siswa introvert, dilakukan uji lapangan operasional pada delapan siswa kelas XI SMA Negeri 1 Pasuruan selama enam kali pertemuan. Pada uji lapangan operasional dilakukan pretest dan posttest dengan menggunakan skala kecemasan dan skala introvert kemudian hasilnya dianalisis menggunakan uji Wilcoxon dengan bantuan SPSSfor windows 20.00 .

Produk pengembangan paket pelatihan menulis ekspresifsebagai media katarsis kecemasan siswa introvert baik untuk siswa dan panduan untuk konselor ini juga didesain secara menarik dengan kombinasi warna yang menarik, gambar penunjang yang tepat dan dapat dipahami oleh siswa serta tata 
layout yang sistematis. Selain itu isi materi yang dibahas dalam paket pelatihan sudah disesuaikan dengan tujuan yaitu mengurangi tingkat kecemasan pada siswa introvert. Panduan bagi konselor diberikan tulisan "panduan untuk konselor" pada sampul depan dan paket pelatihan untuk siswa diberikan tulisan "untuk siswa", hal ini bertujuan untuk membedakan antara paket pelatihan untuk siswa dan untuk konselor, paket pelatihan dicetak sama dengan ukuran kertas A4.

Jadi berdasarkan pemaparan diatas secara keseluruhan dapat ditarik kesimpulan bahwa paket pelatihan menulis ekspresifsebagai media katarsis kecemasan siswa introvert di SMA telah berterima secara teoritis maupun praktis. Selain itu paket pelatihan menulis ekspresifini sudah terbukti efektif untuk mengurangi tingkat kecemasan siswa introvert, namun paket pelatihan ini juga memiliki kelemahan yaitu konselor harus bisa aktif dalam membangun hubungan baik, dan harus dapat meyakinkan siswa agar mau menuliskan ceritanya, serta konselor harus pandai dalam mengartikan tulisan siswa, apakah tulisan tersebut benar atau hanya karangan belaka.

\section{SIMPULAN}

Penelitian ini menghasilkan produk berupa paket pelatihan menulis ekspresifsebagai media katarsis kecemasan siswa introvert dan panduan untuk konselor. Produk yang dikembangkan telah melalui uji ahli, uji calon pengguna, dan uji operasional. Apabila dilihat dari kegunaan (utility), paket pelatihan menulis ekspresifini bermanfaat bagi konselor yaitu sebagai media untuk memberikan pelayanan bimbingan dan konseling dan juga sebagai alternatif untuk membantu siswa mengurangi tingkat kecemasan yang dirasakannya ketika menghadapi masalah dan sulit menceritakannya kepada orang lain. Dari aspek ketepatan (accuracy) paket pelatihan menulis ekspresifini memiliki ketepatan isi yaitu ketepatan materi, aktivitas, tahapan latihan dengan tujuan untuk mengurangi tingkat kecemasan siswa introvert di SMA. Dilihat dari aspek kemenarikan (interestness) paket pelatihan menulis ekspresifini telah didesain dengan warna dan cover yang menarik dan tetap sesuai dengan materi yang disampaikan, kombinasi warna yang tidak berlebihan dan penggunaan font yang jelas semuanya disesuaikan dengan karakteristik siswa SMA. Dari aspek kelayakan (faesibility) paket 
pelatihan menulis ekspresifini layak sebagai media konseling yaitu dilihat dari desain, materi, latihan, kemudahan dalam penggunaan sekaligus efesien dari sisi biaya, waktu dan tenaga yang diperlukan untuk melaksanakan kegiatan konseling kelompok dengan tujuan membantu siswa mengurangi tingkat kecemasan yang dirasakannya.

Adapun kesimpulan dari penelitian pengembangan ini adalah sebagai berikut:

1. Penelitian pengembangan ini menghasilkan sebuah produk yaitu paket pelatihan menulis ekspresifsebagai media katarsis kecemasan siswa introvert. Paket pelatihan tersebut untuk siswa dan panduan untuk konselor.

2. Uji coba terhadap paket pelatihan menulis ekspresifmelalui dua tahap yaitu uji ahli (materi, media, dan bahasa), uji calon pengguna produk (konselor dan siswa).

3. Paket pelatihan menulis ekspresifini sudah melalui uji lapangan operasional. Dari uji lapangan operasional dapat diketahui bahwa paket pelatihan menulis ekspresifefektif untuk menurunkan kadar kecemasan siswa introvert.

4. Paket pelatihan menulis ekspresifini memiliki keunggulan dan kelemahan dalam pengembangannya :

a. Keunggulan dari paket pelatihanmenulis ekspresifini adalah belum pernah ada sebelumnya paket pelatihan sejenis ini, ketika dikembangkan melalui beberapa tahapan uji ahli, uji coba calon pengguna dan uji coba operasional ternyata data yang diperoleh hasilnya memuaskan dan terbukti bahwasannya paket ini efektif untuk mengurangi tingkat kecemasan siswa introvertdalam menghadapi permasalahannya. Peneliti telah mendesain paket pelatihan ini dengan semenarik mungkin agar siswa semangat untuk mengerjakan setiap zona pelatihan di dalamnya, kemenarikan desain tidak mempengaruhi kejelasan materi da nisi paket sehingga semuanya 
seimbang dan

menghasilkan paket

pelatihan yang sesuai

dengan karakteristik siswa

SMA.

b. Kelemahan dari paket pelatihan ini adalah konselor harus sangat cermat dalam memahami setiap tulisan siswa karena ada kemungkinan siswa tidak menuliskan cerita yang jujur. Konselor harus benar-benar mendampingi siswa dan bisa membangun kedekatan yang baik dengan konseli.

\section{DAFTAR PUSTAKA}

Adams, Kathleen. 2013. Expressive Writing Foundatios of Practice.United States Of America: Rowman \& Littlefield Publisher. Dari Google E-book, (Online),

(http://books.google.co.id), diakses 7 November 2014.

Alwisol. 2009. Psikologi Kepribadian Edisi Revisi.UMM Press: Malang

Auliani, Rizqiah. 2010. Hubungan Antara Tipe Kecemasan dengan Pretasi Belajar Statistik Mahasiswa Fakultas Psikologi UIN Jakarta. Jurnal Psikologi UIN Syarief Hidayahtullah Jakarta (Online), (http://www.google.com), diakses 01 Mei 2015.
Bertens, K. 2007.Psikoanalisis Sigmund Freud. Gramedia Pustaka Utama:Jakarta Dari Google E-book, (Online), (http://books.google.co.id), diakses 25 Oktober 2014

Borg, Walter R; Gall, Joyce P \& Gall, Meredith D. 2003. Educational Research An Introduction Seventh Edition. Pearson Education, Inc:United State of America

Pennebaker, J.W. 2002. Ketika diam bukan emas: Berbicara dan menulis sebagai terapi. Mizan: Bandung 